\title{
ANTIBACTERIAL AND ANTIOXIDANT ACTIVITY OF BIOSYNTHESIZED SILVER NANOPARTICLES FROM ULMUS WALLICHIANA PLANCH. LEAF EXTRACT
}

\author{
ANSAR MEHMOOD ${ }^{1} *$, SHAISTA SHABIR ${ }^{1}$, SAJJAD HUSSAIN ${ }^{1}$, KHAWAJA SHAFIQUE \\ AHMAD ${ }^{1}$, ABDUL HAMID ${ }^{2}$ \\ ${ }^{I}$ Department of Botany, University of the Poonch Rawalakot, 12350, Azad Kashmir, Pakistan \\ ${ }^{2}$ Department of Horticulture, University of the Poonch Rawalakot, 12350, Azad Kashmir, Pakistan \\ *corresponding author: ansar.mehmood321@gmail.com
}

Manuscript received: October 2018

\begin{abstract}
Eco-friendly synthesis of metal nanoparticles using plant extract plays a vital role in nanotechnology. This study aimed to produce silver nanoparticles (SNPs) in an eco-friendly manner using leaf extract of Ulmus wallichiana Planch. When the leaf extract was treated with $\mathrm{AgNO}_{3}$, the colour changed from yellowish to dark brown, indicated the formation of SNPs. The obtaining SNPs were pre-dominantly spherical, crystalline and a mean size of $54 \mathrm{~nm}$. FTIR spectrum evidenced that plant's biomolecules acted as reducing agent. The antibacterial activity of SNPs was assessed against Gram positive (Staphyllococcus aureus) and Gram negative (Escherichia coli, Pseudomonas aeruginosa and Klebsiella pneumoniae) bacteria and highest activity was found to be exerted at $1 \mathrm{mg} / \mathrm{mL}$ SNPs against $P$. aeruginosa $(17.63 \mathrm{~mm})$. They also showed profound antioxidant activity against DPPH. Ulmus mediated synthesis of SNPs is eco-friendly, non-toxic and cost effective with good antibacterial and antioxidant effect and can be used in biomedical applications.
\end{abstract}

\section{Rezumat}

Sinteza ecologică a nanoparticulelor metalice folosind extracte de plante joacă un rol vital în industria nanotehnologiilor. Acest studiu a urmărit biosinteza nanoparticulelor de argint (SNP) într-un mod ecologic, folosind extractul foliar de Ulmus wallichiana Planch. După tratarea extractului cu $\mathrm{AgNO}_{3}$, culoarea s-a modificat de la galben la maro închis, indicând formarea nanoparticulelor. SNP-urile obținute au fost predominant sferice, cristaline și au prezentat dimensiunea medie de 54 nm. Spectrul FTIR a evidențiat faptul că biomoleculele din extract au acționat ca agent reducător. Activitatea antibacteriană a nanoparticulelor a fost evaluată asupra bacteriilor Gram pozitive (Staphyllococcus aureus) și Gram negative (Escherichia coli, Pseudomonas aeruginosa și Klebsiella pneumoniae), iar cea mai mare activitate s-a înregistrat pentru doza de $1 \mathrm{mg} / \mathrm{mL}$ SNP asupra $P$. aeruginosa $(17,63 \mathrm{~mm})$. De asemenea, au prezentat o activitate antioxidantă pronunțată în testul DPPH. Sinteza mediată de Ulmus a nanoparticulelor de argint este ecologică, non-toxică și rentabilă, cu efect antibacterian şi antioxidant, având potențiale aplicații biomedicale.

Keywords: collagen, minocycline, spongious delivery systems, freeze-drying

\section{Introduction}

Synthesis, characterization and application of nanomaterials represent currently an essential area of research. Nanotechnology grips promising applications in many fields such as biomedical, bio-sensing, drug delivery, food packaging, cancer therapy, agriculture and cosmetics, and many more fields [1]. The materials having overall size of $100 \mathrm{~nm}$ are considered to be nanoparticles [2]. Nanoparticles exhibit larger surface area to volume ration, which is one of the most important and distinctive property [3]. Nanoparticles made from noble metals such as $\mathrm{Au}$, $\mathrm{Ag}, \mathrm{Pt}$, and Pd are the most efficiently studied nanoparticles nowadays. Among metals, silver nanoparticles have drawn much attention of the researchers due to their wide applications as antimicrobial [4]. They have been recognized to displaying solid antibacterial effect against both Gram negative and Gram positive bacteria $[5,6]$. This antimicrobial proficiency of SNPs permits them to be appropriately engaged in several domestic stuffs such as home appliances, textiles, food packaging, dentistry and medical devices [7, 8].

Additionally, silver is a potent germicide agent that exhibits minor toxicity in human [9]. One of the utmost uses of SNPs is in topical liniments to avoid infection against open wounds and burn [10]. Development of eco-friendly, not toxic and low-cost methods for synthesis of SNPs of different morphologies is an essential feature of nanotechnology [11].

Although different type of physical and chemical methods, for the synthesis of SNPs, these methods have some drawbacks, like high cost, less efficient, slow synthesis and more importantly many toxic chemicals are involved. Therefore, there is a rising 
FARMACIA, 2019, Vol. 67, 4

interest in developing eco-friendly methods for the synthesis of SNPs such as green chemistry procedures which eliminate the use of chemicals known as lethal to environment and also to the human health $[12,13]$. Biological methods using bacteria, fungi and plants are beneficial in contrast to physical and chemicals approaches $[14,15]$. In contrast to microorganism, plants are more advantageous as later reducing the cost and maintenance of culture media [16]. The phytochemicals exist in the plants extracts as a reducing agent and aid in the transformation of silver ions to silver nanoparticles $[17,18]$. They do not embrace the use of costly and lethal chemicals and the raw material is inexpensive and effortlessly accessible [19, 20]. A survey of literature showed that SNPs fabricated from different plant extracts such as Azedirachta indica, Ficus benghalensis [21], Amona reticulata [22], Iresine herbstii [23], Melia azedarach [24] and Berberis lcyium [25] and many more have produced abundant attention in the nanomaterial formation.

Reactive oxygen species (ROS) and free radicals produced degenerative reactions that harm cells and macromolecules. Antioxidants are known to have protective effect against free radicals and ROS [26]. Many plant-based polyphenol substances such as alkaloid and flavonoid have already been reported as antioxidant [27, 28]. Recently it is studied that biosynthesized metal nanoparticles particularly SNPs also scavenge the oxygen based free radicals more effectively [29, 30].

Keeping in view the importance of SNPs, the present study aimed to synthesize SNPs from leaf extract of $U$. walliachiana as an eco-friendly approach and to examine their antibacterial efficiency against common pathogens both Gram positive (S. aureus) and Gram negative (E. coli, $P$. aeruginosa and $K$. pneumoniae) by disc diffusion method and the antioxidant activity by DPPH assay.

\section{Materials and Methods}

\section{Preparation of plant extract}

For the preparation of plant extract, fresh leaves of Ulmus wallichiana Planch. were collected from Rawalakot, Azad Kashmir, Pakistan. The plant was identified with the help of the Pakistan flora and the plant List. The voucher specimen was submitted to the Herbarium, University of the Poonch Rawalakot, Pakistan. The leaves were thoroughly rinsed with tape as well as distilled water to wash out any undesirable and dust particle from the surface of the leaves. The finely chopped leaves of $10 \mathrm{~g}$ were poured into a $250 \mathrm{~mL}$ Erlenmeyer flask with $100 \mathrm{~mL}$ distilled water and boiled for $10 \mathrm{~min}$ on hot plate for the extraction of biomolecules followed by cooling at room temperature. To remove the leaves debris, the extracted solution was filtered through Whatman filter paper no. 1 and the filtrate (leaf extract) was stored at $4^{\circ} \mathrm{C}$ for further use for the synthesis of SNPs.

Synthesis of SNPS

For the phyto-fabrication of SNPs, $2 \mathrm{~mL}$ of plant leaf extract was reacted with $8 \mathrm{~mL}$ of $1 \mathrm{mM} \mathrm{AgNO}_{3}$ solution in a test tube and incubated at room temperature for $24 \mathrm{hrs}$. Silver nitrate of Merck Company was purchased from Lahore. The development of SNPs in the mixture was monitored through colour change and UV-Vis spectroscopy. When Ag ions reduce to SNPs, the colour of the mixture changed to dark brown which is a clue of the SNPs synthesis. The colloidal solution was also scanned by UV-Vis spectroscopy in the wavelength range of 300 to $800 \mathrm{~nm}$ at a resolution of $1 \mathrm{~nm}$ after time intervals of 0,5 , 10 and $15 \mathrm{~min}$ and lastly after $24 \mathrm{~h}$ on a PerkinElmer Lambda 950, UK spectrophotometer. After the sign of the SNPs formation, the reaction solution was centrifuged for $10 \mathrm{~min}$ at $15,000 \mathrm{rpm}$ in order to obtain them in a purified form. The purified SNPs were again re-dispersed in distilled water and centrifuged at the same condition. The process was repeated three times. The purified clean SNPs were characterized by scanning electron microscopy (SEM), X-ray diffraction analysis (XRD) and Fourier transform infrared spectroscopy (FTIR).

\section{Scanning Electron Microscopy}

The surface morphology of the synthesized SNPs was observed in Tescan Mira 3X field emission scanning electron microscope (FESEM). Previously purified SNPs were sonicated in Milli Q water until a dilute suspension of SNPs is formed. A small drop of suspension was placed on carbon tape fastened on the sample (aluminium) tubs and permitted to fully dry below a mercury lamp. These tubs were then examined in FESEM at an accelerating voltage of $20 \mathrm{kV}$.

$X$-ray diffraction analysis

The crystallinity and mean crystalline domain size were determined through XRD. The purified SNPs were freeze dried and powder was subjected to XRD analysis on Bruker D8 Diffractometer with $\mathrm{Cu} \mathrm{K} \mathrm{K}_{\alpha}$ X-ray source of $1.54 \AA$ wavelength. The diffraction pattern was obtained at $2 \theta$ value between the ranges of 10 to 80 with $2^{\circ} \AA$ per min scan rate.

\section{Fourier transform infra-red spectroscopy}

FTIR was used to identify the functional groups of compounds acted as reducing and stabilized agent in the synthesis process of SNPs. The freeze-dried powder of SNPs was analysed in FTIR (Perkin-Elmer Spectrum 100, USA) and the spectrum was recorded between the ranges of 4000 to $400 \mathrm{~cm}^{-1}$ at a resolution of $1 \mathrm{~cm}^{-1}$.

\section{Antibacterial activity}

The bactericidal capability of SNPs was assessed against common drug resistant human bacterial pathogens including Gram positive (Staphyllococcus aureus) and Gram negative (Escherichia. coli, P. aeruginosa and K. pneumoniae) bacteria by disc diffusion method 
[31]. The bacterial pathogens were obtained from Combined Military Hospital (CMH), Muzaffarabad, Pakistan. The experiment was performed in completely randomized design (CRD) with three replicates. Nutrient agar medium was prepared by adding $28 \mathrm{~g}$ of nutrient agar in $1000 \mathrm{~mL}$ distilled water for the cultivation of bacteria. The culture medium and all other requirements were sterilized in an autoclave at $121^{\circ} \mathrm{C}$ for $15 \mathrm{~min}$. A loop of each bacterium from overnight fresh culture was dipped in $10 \mathrm{~mL}$ distilled water in separate test tubes to make bacterial inoculum. A $1 \mathrm{~mL}$ of each bacterial inoculum was taken in corresponding sterile Petri plates. Sterile nutrient agar medium was poured in each Petri plate, mixed well by gently shaking and kept at room temperature for solidification. The filter paper discs of $6 \mathrm{~mm}$ were prepared, sterilized and supplemented with SNPs $(1 \mathrm{mg} / \mathrm{mL})$, aqueous leaf extract $(1 \mathrm{mg} / \mathrm{mL})$, ampicillin $(100 \mu \mathrm{g} / \mathrm{mL})$ as positive control and distilled water as negative control, and placed on solid agar medium at their labelled positions. For the growth of the bacteria, the Petri plates were incubated at $37^{\circ} \mathrm{C}$ for $24 \mathrm{~h}$ and then the zone of inhibition was measured in millimetre around each disc using the meter scale.

Minimum inhibitory concentration (MIC) of SNPS The lowest amount of the antimicrobial agent that inhibits the growth of bacteria after $24 \mathrm{~h}$ is known as MIC. A serial dilution of SNPs such 1, 0.5, 0.25 and $0.125 \mathrm{mg} / \mathrm{mL}$ was made and tested by disc diffusion method. The experiment was performed same as in antimicrobial activity. After $24 \mathrm{~h}$ of incubation, zones of inhibition were measured around the discs.

\section{Antioxidant Activity}

The antioxidant activity of biosynthesized SNPs and plant extract was evaluated by DPPH (2,2-diphenyl1-picrylhydrazyl) assay [32]. A stock solution of DPPH was prepared by adding $7 \mathrm{mg}$ DPPH in 100 $\mathrm{mL}$ 95\% methanol. The leaf extract and SNPs were mixed in methanol to make their stock solution $(0.1$ $\mathrm{mg} / \mathrm{mL}$ ). From this stock solution, 2, 4 and $6 \mathrm{~mL}$ of each leaf extract and SNPs were taken in 3 separate test tubes and, by serial dilution, the final volume of each test tube was raised to $10 \mathrm{~mL}$ with same solvent whose concentration was then $20 \mu \mathrm{g} / \mathrm{mL}, 40$ $\mu \mathrm{g} / \mathrm{mL}$ and $60 \mu \mathrm{g} / \mathrm{mL}$ respectively. Freshly prepared DPPH solution was added in each of the test tube containing leaf extract and SNPs, vortexed vigorously and incubated for $30 \mathrm{~min}$ in dark at room temperature. The optical density of each of the sample was recorded at $517 \mathrm{~nm}$ using UV-Vis spectrophotometer (PerkinElmer Lambda 950, UK). The antioxidant activity was assessed by calculating the \% inhibition using the following formula:

$\%$ scavenging activity $=\frac{(\mathrm{OD} \text { control-OD sample })}{\mathrm{OD} \text { control }} \times 100$,

where, OD control is the optical density of DPPH + methanol and OD sample is the optical density of
$\mathrm{DPPH}+$ sample (leaf extract and SNPs). The $\mathrm{IC}_{50}$ was calculated by using the regression line equation against different concentrations of tested samples.

\section{Statistical analysis}

The experiments were performed in completely randomized design (CRD) with three replicates. The data was subjected to analysis of variance (ANOVA) using MSTAT C software and means were compared by Duncan's multiple range test (DMRT).

\section{Results and Discussion}

Synthesis and characterization of SNPS

SNPs were synthesized from the aqueous leaf extract of $U$. wallichiana. When the aqueous leaf extract was added in $\mathrm{AgNO}_{3}$ solution, the colour of the reaction was started to change from yellowish to reddish brown, indicating the SNPs synthesis (Figure 1).
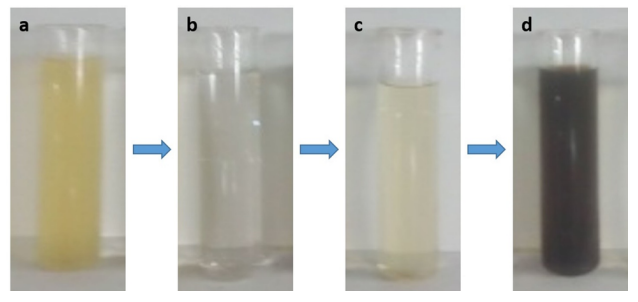

Figure 1.

Visual observation of formation of SNPs from the leaf extract of $U$. wallichiana: (a) leaf extract; (b) $\mathrm{AgNO}_{3}$ solution; (c) leaf extract $+\mathrm{AgNO}_{3}$ at zero time and (d) leaf extract $+\mathrm{AgNO}_{3}$ after $24 \mathrm{~h}$

The change of the colour in the reaction mixture is the first visual evidence of the SNPs formation [30]. A reddish brown colour is a characteristic feature of the SNPs in the solution [33]. A rapid change in colour (just within $5 \mathrm{~min}$ ) was observed which indicates the increased rate of reaction. This change within the optical properties of the colloidal solution is also linked with the change in Surface Plasmon Resonance (SPR) excited when $\mathrm{Ag}^{+}$changes to $\mathrm{Ag}^{0}$ [34]. This formation of SNPs as indicated by the colour change was further supported by taking UV-Vis spectra of the colloidal solution as a time function (Figure 2). The spectra were recorded after $0,5,10$ and $15 \mathrm{~min}$ and finally after $24 \mathrm{~h}$. There was no absorption band at zero time but when reaction time proceeded to 5 min, a characteristic SPR band was centred at 439 $\mathrm{nm}$. After 10 and $15 \mathrm{~min}$, the SPR bands were developed at 446 and $450 \mathrm{~nm}$ respectively. For observing the stability of SNPs, the reaction was left for $24 \mathrm{~h}$ and the absorption spectrum was recorded showing an SPR band at $456 \mathrm{~nm}$. The intensity of absorption was increased with the passage of time, indicating the increased concentration of SNPs in the solution. It is a fact well established that, in the aqueous solution, SNPs exhibit absorption spectrum in the wavelength range of 400 to $500 \mathrm{~nm}$ [35]. It was 
FARMACIA, 2019, Vol. 67, 4

also proposed that number and width of absorption bands are associated with the shape and the size distribution of the synthesized SNPs in the solution [36]. A single SPR band in the wavelength range of 300 to $700 \mathrm{~nm}$ corresponds to pre-dominantly spherical particles [37]. It was also observed in our study that SPR band shifted from 439 to $456 \mathrm{~nm}$ (red shift) with the reaction time. This red shift suggested an increase in the mean size of SNPs [38].

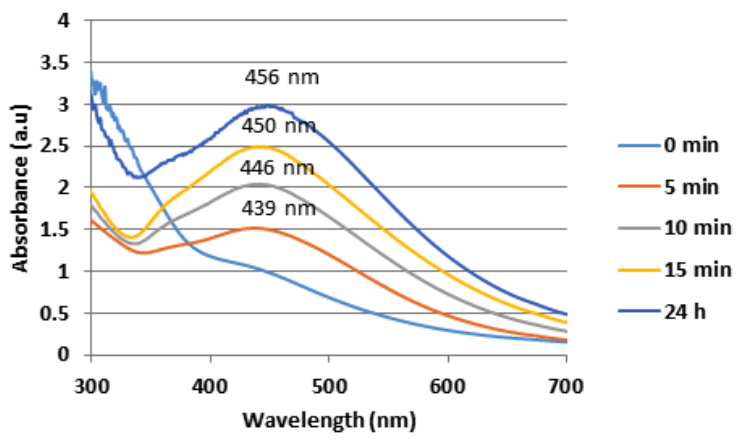

Figure 2.

UV-Vis spectra of colloidal solution of leaf extract of U. wallichiana and $\mathrm{AgNO}_{3}$ at different time of intervals such as $0,5,10$ and $15 \mathrm{~min}$ and finally after $24 \mathrm{~h}$

After the evidence of formation of SNPs by colour change and UV-Vis spectroscopy, they were further confirmed by analysing their surface morphology in FESEM. Figure 3 shows the SEM micrograph of SNPs which manifests that most of the particles are predominantly spherical with mean size of $54 \mathrm{~nm}$. Due to small size, the individual particles were aggregated to clusters [39]. Earlier studies also support the result of SEM [40, 41]. The biosynthesized SNPs were further characterized by XRD which gives information about the crystalline nature and the phase of nanoparticles.

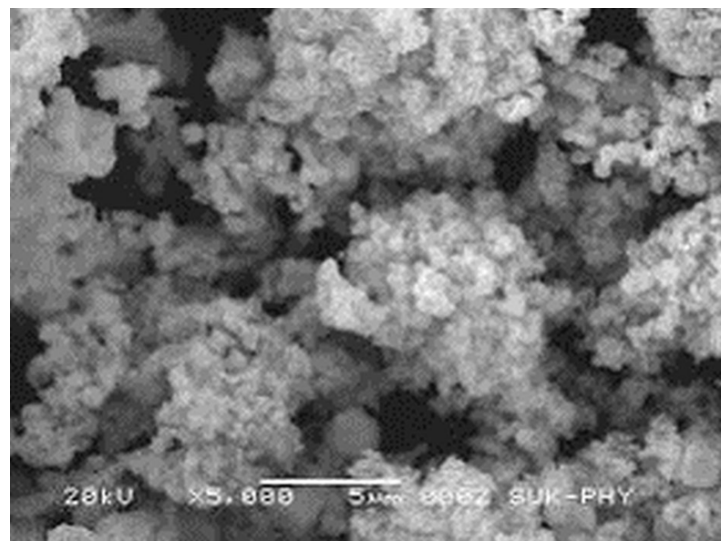

Figure 3.

The morphology and size of the purified SNPs showed by the SEM micrograph

The diffraction pattern is shown in Figure 4, it manifests diffraction peaks at 2 values of $37.95^{\circ}, 44.05^{\circ}, 64.30^{\circ}$ and $78.45^{\circ}$ which corresponds to (111) (200), (220) and (311) crystalline planes of face centred cubic silver compared with the standard powder diffraction card, silver file (JCPDS No. 04-0783). Our results are also supported by previous studies as well $[30,42]$. The functional groups of compounds, present in the plant extract, involved in the chemical transformation of Ag ions to SNPs were identified with the help of FTIR spectrum of SNPs as shown in Figure 5. The transmission bands were centred at 1010, 1100, 1430, 1550, 1650, 2025, 2987 and 3406 which are associated with $-\mathrm{C}-\mathrm{O}-$ phenolic groups, $\mathrm{C}=\mathrm{C}$ aromatic amides, $\mathrm{N}-\mathrm{H}$ bending vibrations of primary amines and $\mathrm{O}-\mathrm{H}$ stretching vibrations of phenolic compounds. The presence of functional groups indicates that SNPs are capped by the biomolecules of plant extract. These biomolecules served as reducing agent and reduced $\mathrm{Ag}$ ions to SNPs. It is a well fact established that biomolecules such as phenol, alkaloid, flavonoid and protein present in plant extract synthesized SNPs $[41,43]$.

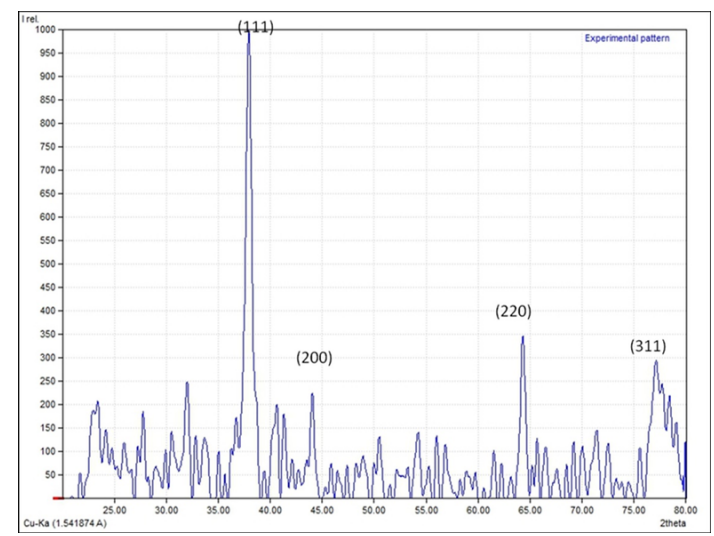

Figure 4.

The crystalline nature of SNPs demonstrated by the XRD pattern

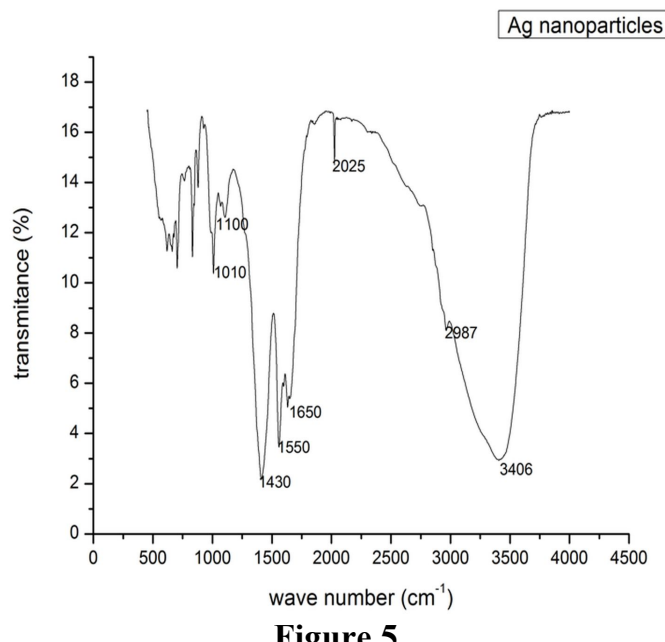

FTIR spectrum of SNPs

Antibacterial activity of SNPS

Many antibiotics and other antibacterial agents have been used to inhibit the growth of common human pathogens in various industries. But these antibacterial 
FARMACIA, 2019, Vol. 67, 4

sources are now facing a problem of multidrug resistant power in pathogens. Therefore, there is a need to focus on alternative ways to overcome the microbial drug resistance. In this research, we scrutinized the antibacterial power of the biosynthesized SNPs against common human pathogens both Gram positive $(S$. aureus) and Gram negative (E. coli, P. aeruginosa and $K$. pneumoniae) bacteria.

The results of antibacterial activity of SNPs, plant extract, positive control (ampicillin) and negative control (distilled water) are presented in Table I. Statistically a significant difference was found among the tested bacteria as well as among the treatments. The highest

inhibitory activity was shown by SNPs $(1 \mathrm{mg} / \mathrm{mL})$ against $P$. aeruginosa $(17.63 \mathrm{~mm})$ followed by $E$. coli $(17.60 \mathrm{~mm})$, S. aureus $(17.00 \mathrm{~mm})$ and $K$. pneumoniae $(14.67 \mathrm{~mm})$. The antibacterial activity of ampicillin was $15.67,16.00,16.37$ and $6.80 \mathrm{~mm}$ against $E$. coli, $S$. aureus, $P$. aeruginosa and $K$. pneumoniae respectively. The plant extract and distilled water displayed no antibacterial activity. Among the bacteria, $P$. aeruginosa was more sensitive towards SNPs followed by E. coli, $S$. aureus and $K$. pneumoniae. From our results it is clearly observed that biosynthesized SNPs from $U$. wallichiana leaf extract have higher antibacterial potential when compared to ampicillin.

Table I

Antibacterial activity of SNPs, plant extract, positive control and negative control against four common human pathogens

\begin{tabular}{|l|c|c|c|c|c|}
\hline \multirow{2}{*}{ Names } & \multicolumn{5}{|c|}{ Zone of Inhibition in millimetres (mm) } \\
\cline { 2 - 6 } & Ampicillin & AgNPs (1 mg/mL) & Leaf aqueous extract & Distilled water & Means \\
\hline S. aureus & 16 & 17.13 & 0 & 0 & $8.28^{\mathrm{A}}$ \\
\hline E. coli & 15.67 & 17.60 & 0 & 0 & $8.32^{\mathrm{A}}$ \\
\hline P. aeruginosa & 16.37 & 17.63 & 0 & 0 & $8.50^{\mathrm{A}}$ \\
\hline K. pneumoniae & 6.80 & 14.67 & 0 & 0 & $5.37^{\mathrm{B}}$ \\
\hline Means & $13.70^{\mathrm{B}}$ & $17.18^{\mathrm{A}}$ & $0^{\mathrm{C}}$ & 0 & \\
\hline
\end{tabular}

The same letter (s) in a row or column represents non-significant results at $\mathrm{p}=0.05$ by DMRT

Table II

MIC of SNPs against four common human pathogens

\begin{tabular}{|l|c|c|c|c|c|}
\hline \multirow{2}{*}{ Name } & \multicolumn{5}{|c|}{ Zone of Inhibition in millimetres (mm) } \\
\cline { 2 - 6 } & AgNPs (1 mg/mL) & AgNPs (0.5 mg/mL) & AgNPs (0.25 mg/mL) & AgNPs (0.125 mg/mL) & Means \\
\hline S. aureus & 17.13 & 13.80 & 10 & 0 & $10.23^{\mathrm{B}}$ \\
\hline E. coli & 17.60 & 14.70 & 7.40 & 0 & $9.93^{\mathrm{BC}}$ \\
\hline P. aeruginosa & 17.63 & 14.40 & 11.20 & 7.40 & $12.66^{\mathrm{A}}$ \\
\hline K. pneumoniae & 14.67 & 11.80 & 6.06 & 0 & $8.13^{\mathrm{C}}$ \\
\hline Means & $13.70^{\mathrm{A}}$ & $16.75^{\mathrm{B}}$ & $8.70^{\mathrm{C}}$ & $\mathbf{0}$ & \\
\hline
\end{tabular}

The same letter (s) in a row or column represents non-significant results at $p=0.05$ by DMRT

SNPs were further tested for their MIC value and results are shown in Table II. Previously tested 1 $\mathrm{mg} / \mathrm{mL}$ SNPs were further diluted in distilled water in serial dilution of $1 \mathrm{mg} / \mathrm{mL}, 0.5 \mathrm{mg} / \mathrm{mL}, 0.25 \mathrm{mg} / \mathrm{mL}$ and $0.125 \mathrm{mg} / \mathrm{mL}$ in four separate test tubes. The MIC of SNPs was $0.125 \mathrm{mg} / \mathrm{mL}$ against $P$. aeruginosa and $0.25 \mathrm{mg} / \mathrm{mL}$ against all other tested bacteria.

The biosynthesized SNPs have shown very profound antibacterial activity against both Gram positive and Gram negative bacteria even at very low concentration [44]. Lesser concentration of SNPs is considered benign for the human consumption but lethal against the microorganisms [14]. In our study, Gram negative bacteria were found more susceptible to SNPs. Previously SNPs have also inhibited the growth of negative bacteria more intensely than Gram positive bacteria because $\mathrm{Ag}^{+}$possesses positive charge which interact with negatively charged cell membrane of Gram negative bacteria with better affinity, creating holes in the membrane, thus restricting their function $[45,46]$.

There are several proposed mechanisms regarding the action of SNPs to inhibit to growth of bacteria. It is found that size and shape of nanoparticles determine the antibacterial activity as spherical shaped and smaller sized nanoparticles have been studied to show good antibacterial activity [47, 48]. The smaller is the size of SNPs, the larger is the surface area, resulting a high antibacterial activity [49]. It is believed that SNPs release Ag in the ionic form on the surface of bacteria which create inhibitory effect on their growth [50]. SNPs interact with cell membrane and disturb the cell membrane permeability and metabolic pathway. They penetrate through cell membrane, interact with chromosome, bind to DNA and block DNA replication [14]. In E. coli it is reported that SNPs decrease enzymatic activity by damaging cell membrane and cause death of E. coli. Biosynthesized SNPs are new alternatives to antibiotics and other antibacterial agents, because former has less probability of evolving resistance [51].

Antioxidant Activity

The antioxidant potential of biosynthesized SNPs, plant extract and standard (ascorbic acid) was determined by DPPH radical scavenging assay. The biosynthesized SNPs efficiently scavenged free radicals of DPPH as 
compared to plant extract and ascorbic acid (Figure 6). The antioxidant activity of SNPs was $36.44,53.76$ and $81.24 \%$ at 20,40 and $60 \mu \mathrm{g} / \mathrm{mL}$ concentration respectively.

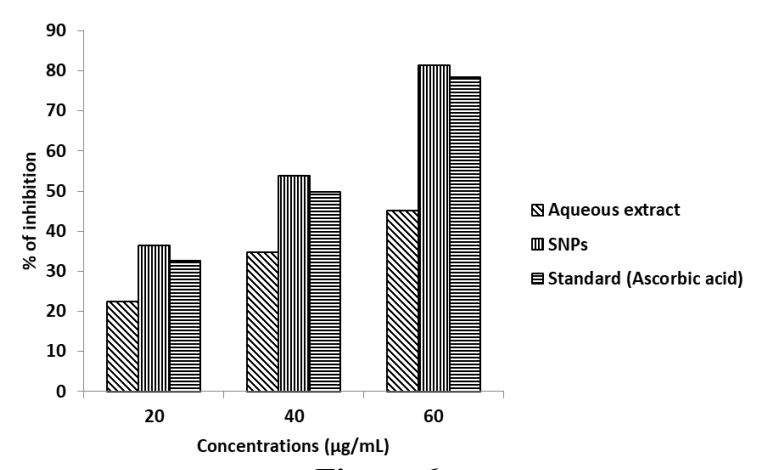

Figure 6.

Free radical scavenging activity of SNPs, plant extract and ascorbic acid against DPPH radicals

The DPPH results were further interpreted by the calculation of $\mathrm{IC}_{50}$ (the concentration required to inhibit $50 \%$ of the DPPH) value of SNPs and plant extract (Figure 7). SNPs exhibited $\mathrm{IC}_{50}$ value (33.62 $\mu \mathrm{g} / \mathrm{mL})$ better than ascorbic acid $(36.91 \mu \mathrm{g} / \mathrm{mL})$. The $\mathrm{IC}_{50}$ value of plant extract was $68.19 \mu \mathrm{g} / \mathrm{mL}$. The lowest $\mathrm{IC}_{50}$ value of SNPs indicates their higher antioxidant activity. A variety of bioactive compounds such as polyphenols, alkaloids, proteins etc. those are present in the $U$. wallichiana [52] leaves act as hydrogen donor to free radical and thus break the chain reaction of free radical [53]. The enhanced antioxidant activity of biosynthesized SNPs is due to the capping of these biomolecules.

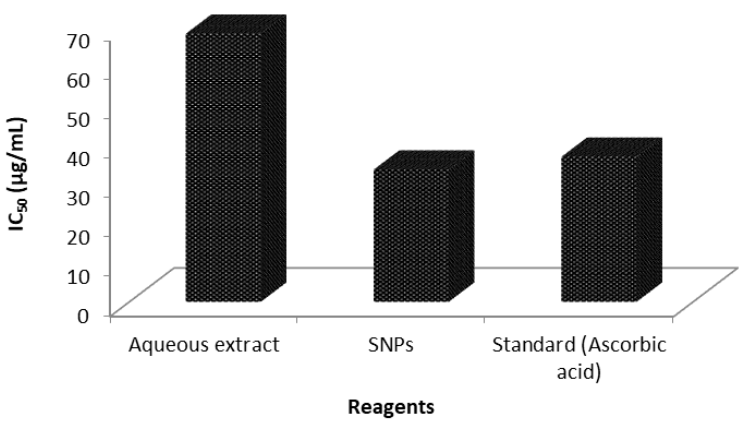

Figure 7.

$\mathrm{IC}_{50}$ value of SNPs, plant extract and standard control (ascorbic acid)

\section{Conclusions}

In this research, we developed an environmentally sustainable process for the synthesis of SNPs from leaf extract of Ulmus wallichiana for the first time and it synthesized SNPs within five minutes, a very fast synthesis. The synthesized SNPs were in predominantly spheroid shape with mean size of $54 \mathrm{~nm}$. The biomolecules present in plant extract served as reducing, capping and stabilizing agent of SNPs. When these synthesized SNPs were applied to find their antibacterial and antioxidant activity, they effectively inhibited the growth of common human pathogens and also potentially scavenged DPPH radicals. In conclusion, this synthesis process of SNPs is rapid, non-toxic, low cost and sustainable with environment. Due to effective antibacterial and antioxidant activities, the synthesized SNPs can be used in biomedical applications.

\section{Acknowledgement}

This project is not funded by any organization. We are thankful to Department of Botany, University of Azad Jammu and Kashmir (UAJK) Muzaffarabad, for providing laboratory facilities. We also thank Institute of Space Technology (IST) Islamabad, for FESEM and XRD analysis.

\section{References}

1. Ahmed S, Ahmad M, Swami BL, Ikram S, A review on plants extract mediated synthesis of silver nanoparticles for antimicrobial applications: a green expertise. $J$ Adv Res., 2016; 7(1): 17-28.

2. Nagaich U, Nanocosmeceuticals: a boon to personal care products. J Adv Pharm Technol Res., 2016; 7(1): 17-28.

3. Albrecht MA, Evans CW, Raston CL, Green chemistry and the health implications of nanoparticles. Green Chem., 2006; 8: 417-432.

4. Shankar S, Chorachoo J, Jaiswal L, Voravuthikunchai SP, Effect of reducing agent concentrations and temperature on characteristics and antimicrobial activity of silver nanoparticles. Mater Lett., 2014; 137: 160-163.

5. Zhao G, Stevens SE, Multiple parameters for the comprehensive evaluation of the susceptibility of Escherichia coli to the silver ion. Biometals, 1998; 11: 27-32.

6. Jiang $\mathrm{H}$, Manolache S, Wong ACL, Denes FS, Plasma enhanced deposition of silver nanoparticles onto polymer and metal surfaces for the generation of antimicrobial characteristics. $J$ Appl Polym Sci., 2004; 93: 1411-1422.

7. Gaetano FD, Ambrosio L, Raucci MG, Marotta A, Catauro M, Sol-gel processing of drug delivery materials and release kinetics. J Mater Sci Mater Med., 2005; 16: 261-265.

8. Marambio-Jones C, Hoek EMV, A review of the antibacterial effects of silver nanomaterials and potential implications for human health and the environment. J Nanopart Res., 2010; 12(5): 1531-1551.

9. Farooqui MDA, Chauhan PS, Krishnamoorthy P, Shaik $\mathrm{J}$, Extraction of silver nanoparticles from the left extracts of Clerodendrum incerme. Dig J Nanomater Biostruct., 2010; 5(1): 43-49.

10. Ip M, Lui SL, Poon VKM, Lung I, Burd A, Antimicrobial activities of silver dressings: an in vitro comparison. J Med Microbiol., 2006; 55(1): 59-63.

11. Chandran SP, Chaudhary M, Pasricha R, Ahmad A, Sastry M, Synthesis of gold nanotriangles and silver nanoparticles using Aloe vera plant extract. Biotechnol Prog., 2006; 22(2): 577-583. 
FARMACIA, 2019, Vol. 67, 4

12. Bansal P, Jaggi N, Rohilla SK, "Green" Synthesis of CdS nanoparticles and effect of capping agent concentration on crystallite size. Res J Chem Sci., 2012; 2: 69-71.

13. Nadagouda MN, Varma RS, Green synthesis of silver and palladium nanoparticles at room temperature using coffee and tea extract. Green Chem., 2008; 10: 859-862.

14. Sharma VK, Yngard RA, Lin Y, Silver nanoparticles: green synthesis and their antimicrobial activities. $A d v$ Colloid Interface Sci., 2009; 145: 83-96.

15. Patil SV, Borase HP, Patil CD, Biosynthesis of silver nanoparticles using latex from few Euphorbian plants and their antimicrobial potential. Appl Biochem Biotec., 2012; 167: 776-790.

16. Garima S, Riju B, Kunal K, Ashish RS, Rajendra PS, Biosynthesis of silver nanoparticles using Ocimum sanctum (Tulsi) leaf extract and screening its antimicrobial activity. J Nanopart Res., 2011; 13(7): 29812988.

17. Bar H, Bhui DK, Sahoo GP, Sarkar P, De SP, Misra A, Green Synthesis of Silver Nanoparticles Using Latex of Jatropha curcas. Colloids Surf A Physicochem Eng Asp., 2009; 339: 134-139.

18. Shameli K, Ahmad MB, Zamanian A, Sangpour P, Shabanzadeh P, Abdollahi Y, Zargar M, Green biosynthesis of silver nanoparticles using Curcuma longa tuber powder. Int J Nanomed., 2012; 7: 5603-5610.

19. Chowdhury S, Basu A, Kundu S, Green synthesis of protein capped silver nanoparticles from phytopathogenic fungus Macrophomina phaseolina (Tassi) Goid with antimicrobial properties against multidrug-resistant bacteria. Nanoscale Res Lett., 2014; 9(1): 365: 1-11.

20. Durán N, Marcato PD, Alves OL, De-Souza GI, Esposito E, Mechanistic aspects of biosynthesis of silver nanoparticles by several Fusarium oxysporum strains. J Nanobiotechnol., 2005; 3: 1-8.

21. Saxena A, Tripathi RM, Zafar F, Singh P, Green synthesis of silver nanoparticles using aqueous solution of Ficus benghalensis leaf extract and characterization of their antibacterial activity. Mater Lett., 2012; 67: 91-94.

22. Singh PS, Vidyasagar GM, Biosynthesis, characterization, and antidermatophytic activity of silver nanoparticles using raamphal plant (Annona reticulata) aqueous leaves extract. Ind J Mat Sci., 2014; ID 412452: 1-5.

23. Dipankar C, Murugan S, The green synthesis, characterization and evaluation of the biological activities of silver nanoparticles synthesized from Iresine herbstii leaf aqueous extracts. Coll Surf B: Biointerf., 2012; 98: 112-119.

24. Mehmood A, Murtaza G, Bhatti TM, Raffi M, Kausar $\mathrm{R}$, Antibacterial efficacy of silver nanoparticles synthesized by a green method using bark extract of Melia azedarach L. J Pharm Innov., 2014; 9: 238-245.

25. Mehmood A, Murtaza G, Bhatti TM, Kausar R, Enviro-friendly synthesis of silver nanoparticles using Berberis lycium leaf extract and their antibacterial efficacy. Acta Metall Sin (Eng Lett.), 2014; 27(1), 75-80.

26. Hermans N, Cos P, Maes L, De-Bruyne T, Berghe DV, Vlietinck AJ, Pieters L, Challenges and pitfalls in antioxidant research. Curr Med Chem., 2007; 14: $417-430$
27. Agati G, Azzarello E, Pollastri S, Tattini M, Flavonoids as antioxidants in plants: location and functional significance. Plant Sci., 2012; 196: 67-76.

28. Dajas F, Life or death: neuroprotective and anticancer effects of quercetin. $J$ Ethnopharmacol., 2012; 143: 383-396.

29. Du L, Suo S, Wang G, Jia H, Liu KJ, Zhao B, Liu $\mathrm{Y}$, Mechanism and cellular kinetic studies of the enhancement of antioxidant activity by using surfacefunctionalized gold nanoparticles. Chemistry, 2012; 19: 1281-1287.

30. Otunola GA, Afolayan AJ, In vitro antibacterial, antioxidant and toxicity profile of silver nanoparticles green synthesized and characterized from aqueous extract of a spice blend formulation. Biotech Biotech Equip., 2018; 32(3): 724-733.

31. Bauer A, Kirby W, Sherris JC, Turck M, Antibiotic susceptibility testing by a standardized single disk method. Am J Clin Pathol., 1996; 45: 493-496.

32. Amarowicz R, Estrella I, Hernández T, Robredo S, Troszyńska A, Kosińska A, Pegg RB, Free radicalscavenging capacity, antioxidant activity, and phenolic composition of green lentil (Lens culinaris). Food Chem., 2010; 121: 705-711.

33. Alsalhi MS, Devanesan S, Alfuraydi AA, Vishnubalaji R, Munusamy MA, Murugan K, Nicoletti M, Benelli G, Green synthesis of silver nanoparticles using Pimpinella anisum seeds: antimicrobial activity and cytotoxicity on human neonatal skin stromal cells and colon cancer cells. Int J Nanomed., 2016; 11: 4439-4449.

34. Mittal AK, Chisti Y, Banerjee UC, Synthesis of metallic nanoparticles using plant extracts. Biotech Adv., 2013; 31(2): 346-356.

35. Zargar M, Hamid AA, Bakar FA, Shamsudin MN, Shameli K, Jahanshiri F, Farahani F, Green synthesis and antibacterial effect of silver nanoparticles using Vitex negundo L. Molecules, 2011; 16: 6667-6676.

36. Teponno RB, Tapondjou AL, Gatsing D, Djoukeng JD, Abou-Mansour E, Tabacchi R, Tane P, StoekliEvans H, Lontsi D, Bafoudiosbulbins A and B, two anti-salmonellal clerodane diterpenoids from Dioscorea bulbifera L. var sativa. Phytochemistry, 2006; 67: 1957-1963.

37. Raza MA, Kanwal Z, Rauf A, Sabri AN, Riaz S, Naseem S, Size- and shape-dependent antibacterial studies of silver nanoparticles synthesized by wet chemical routes. Nanomaterials, 2016; 6: 74: 1-15.

38. Vasireddy R, Paul R, Mitra AK, Green Synthesis of Silver Nanoparticles and the Study of Optical Properties. Nanomater Nanotechnol., 2012; 2: 1-6.

39. Pattabiraman S, Tamilselvan A, Karuthapandian S, Mehalingam P, Green Synthesis of silver nanoparticles, characterization, screening of phytochemicals, assessment of antioxidant and antimicrobial activity using the bark extracts of Mimusops elengi L. Energy Environ Focus, 2016; 5: 200-206.

40. Huang J, Zhan G, Zheng B, Sun D, Lu F, Lin Y, Chen $\mathrm{H}$, Zheng Z, Zheng Y, Biogenic silver nanoparticles by Cacumen platycladi extract: synthesis, formation mechanism, and antibacterial activity. Ind Eng Chem Res., 2011; 50: 9095-9106.

41. Ghosh S, Patil S, Ahire M, Kitture R, Kale S, Pardesi K, Cameotra SS, Bellare J, Dhavale DD, Jabgunde A, Synthesis of silver nanoparticles using Dioscorea 
bulbifera tuber extract and evaluation of its synergistic potential in combination with antimicrobial agents. Int J Nanomed., 2012; 7: 483-496.

42. Mehmood A, Murtaza G, Bhatti TM, Raffi M, Facile green approach to investigate morphology controlled formation mechanism of silver nanoparticles. $J$ Clust Sci., 2016; 27: 1797-1814.

43. Udayasoorian C, Kumar RV, Jayabalakrishnan M, Extracellular synthesis of silver nanoparticles using leaf extract of Cassia auriculata. Dig J Nanomater Biostruct., 2011; 6(1): 279-283.

44. Rasheed T, Bilal M, Li C, Iqbal HMN, Biomedical Potentialities of Taraxacum officinale-based Nanoparticles Biosynthesized Using Methanolic Leaf Extract. Curr Pharm Biotechnol., 2017; 18(14): 1116-1123.

45. Sondi I, Salopek-Sondi B, Silver nanoparticles as antimicrobial agent: a case study on $E$. coli as a model for Gram-negative bacteria. J Colloid Interface Sci., 2004; 275(1): 177-182.

46. Gogoi SK, Gopinath P, Paul A, Ramesh A, Ghosh SS, Chattopadhyay A, Green fluorescent protein expressing Escherichia coli as a model system for investigating the antimicrobial activities of silver nanoparticles. Langmuir, 2006; 22(22): 9322-9328.

47. Jain N, Bhargava A, Rathi M, Dilip RV, Panwar J, Removal of protein capping enhances the antibacterial efficiency of biosynthesized silver nanoparticles. PLOS ONE, 2015; 10(7): e0134337.
48. Zhang Y, Yang D, Kong Y, Wang X, Pandoli O, Gao $\mathrm{G}$, Synergetic antibacterial effects of silver nanoparticles of Aloe vera prepared via a green method. Nano Biomed Eng., 2010; 2: 252-257.

49. Kvitek L, Panacek A, Soukupova J, Kolar M, Vecerova R, Prucek R, Holecova M, Zboril R, Effect of surfactants and polymers on stability and antibacterial activity of silver nanoparticles (NPs). J Physical Chem., 2008; 112: 5825-5834.

50. Lee D, Cohen RE, Rubner MF, Antibacterial properties of Ag nanoparticle loaded multilayers and formation of magnetically directed antibacterial microparticles. Langmuir, 2005; 21: 9651-9659.

51. Savithramma N, Linga RM, Ankanna S, Venkateswarlu $\mathrm{P}$, Screening of medicinal plants for effective biogenesis of silver nano particles and efficient anti-microbial activity. Int J Pharm Sci Res., 2012; 3(4): 1141-1153.

52. Bora KS, Kumar A, Bisht G, Evaluation of antimicrobial potential of successive extracts of Ulmus wallichiana Planch. J Ayurveda Integr Med., 2018; 9(3): 190-194.

53. Krishnaraj C, Jagan E, Rajasekar S, Selvakumar P, Kalaichelvan PT, Synthesis of silver nanoparticles using Acalypha indica leaf extracts and its antibacterial activity against water borne pathogens. Colloid Surf B Biointer., 2010; 76(1): 50-56. 